\title{
Risk factors of coronary heart disease in children and young adults with parental history of premature coronary heart disease
}

\author{
Murti Andriastuti, MD; Sudigdo Sastroasmoro, MD, PhD; Agus Firmansyah, MD, PhD
}

\begin{abstract}
Background Morbidity and mortality of coronary heart disease (CHD) are recently increasing. This is related to changes in lifestyle, such as lack of activity and high consumption of fatty diet. The main cause of $\mathrm{CHD}$ is atherosclerosis. The development of atherosclerosis takes a long time, is asymptomatic, and might begin in childhood. The important risk factors that have roles in increasing the likelihood of atherosclerosis are family history of premature CHD, hypertension, hyperlipidemia, obesity, smoking and irregular activity.

Objective The aim of this study was to find out the prevalence of CHD risk factors in children and young adults who had parental history of premature CHD.

Methods This was a descriptive cross sectional study conducted on offspring of premature CHD patients who were admitted in the intensive cardiology care unit (ICCU) of Cipto Mangunkusumo Hospital between January 1999 to December 2001 and of premature CHD patients who visited the Cardiology Clinic of the Department of Internal Medicine, Cipto Mangunkusumo Hospital during March and April 2002. Subjects were aged 12 to 25 year-old.

Results Among the subjects, $40 \%$ had hyperlipidemia, $8 \%$ had hypertension, $11 \%$ were obese, $21 \%$ were active smokers, $41 \%$ were passive smokers, and $73 \%$ had irregular activity. Ninety-seven percents subjects had more than 1 risk factors.

Conclusions The prevalence of hyperlipidemia, hypertension, obesity, passive smoker, active smoker and irregular activity in children and young adults with parental history of premature CHD in this study were higher than those in the normal population. Most had more than 1 risk factor, increasing the likelihood of CHD. A screening test should be performed on children with parental history of premature $\mathrm{CHD}$ so that early preventive measures might be done to minimize the risk factors [Paediatr Indones 2003;43:51-58].
\end{abstract}

Keywords: premature coronary heart disease, parental history, risk factors, children, young adults.
7 he increase of morbidity and mortality of CHD is not only a problem of the developed countries but also of the developing countries. This is closely related o the changes of lifestyle and excessive consumption of fatty diet. ${ }^{1-5}$ The main cause of $\mathrm{CHD}$ is atherosclerosis. ${ }^{6}$ Atherosclerosis is an abnormality consisting of the development of focal fibrolipid in the form of protruding plaques called atheroma in tunica intima and tunica media layers. The atheroma then develops and various complications such as calcification, bleeding, ulceration and thrombosis might occur. ${ }^{6,7}$ Coronary heart disease is a disease of adults but starts at childhood and adolescent. ${ }^{1,8-12}$ The progression is very slow so that it takes a long time from the first symptom such as angina pectoris, to the development of myocardial infarction, which is the early manifestation of CHD, until the sudden death in middle age. $6,13,14$

The development of CHD is affected by some risk factors such as the presence of family history

From the Department of Child Health, Medical School, University of Indonesia, Cipto Mangunkusumo Hospital, Jakarta.

Reprint requests to: Murti Andriastuti, MD, Department of Child Helath, Medical School, University of Indonesia, Cipto Mangunkusumo, Jakarta, Indonesia. Tel. 62-21-390 7740, Fax. 62-21-390 7743. 
of premature $\mathrm{CHD}$, hyperlipidemia, hypertension, obesity, diabetes mellitus, smoking and irregular activity. ${ }^{1,2,12,15-19}$ The important risk factor that might facilitate the development of the other risk factors is the presence of family history of premature CHD. 17,20,21 The more risk factors one has the higher the probability to develop CHD. American Academy of Pediatric (AAP) recommends doing a screening of lipoprotein analysis on children with family history of premature CHD in parents/grandparents so that early preventive measures might be done. ${ }^{22}$

The aim of this study was to obtain data of risk factors such as hypertension, hyperlipidemia, obesity, active and passive smoker, irregular activity and lipid profile in children and young adults who had a history of either one or both parents suffered from early CHD.

\section{Methods}

This was a descriptive cross sectional study. The subjects of this study were offspring of premature CHD patients admitted in ICCU of the Department of Internal Medicine, Medical School, University of Indonesia-Cipto Mangunkusumo Hospital between January 1999 and December 2001 and or visited the Cardiology Clinic on March and April 2002. The data of premature CHD patients were collected from medical records. Inclusion criteria were healthy offspring, aged $12-25$ year-old, where one or both parents suffered from CHD before the age of 55. This study was approved by the Committee of the Medical Research Ethics of the Faculty of Medicine, University of Indonesia, and the required informed consent was signed by the parents. Blood sampling was taken after a 12-hour fasting. Lipid profile was examined with direct enzymatic method and assessed using Hitachi 737 computer in the Clinical Pathology Laboratory of the Cipto Mangunkusumo Hospital.

Parental history of premature CHD was defined as either one or both subjects' biological father and mother suffered from CHD before the age of $55 .^{22}$ Total cholesterol was classified into 3 categories, i.e. normal $(<170 \mathrm{mg} / \mathrm{dl})$, borderline $(170-199 \mathrm{mg} / \mathrm{dl})$, and high $(\geq 200 \mathrm{mg} / \mathrm{dl})$. LDL cholesterol was divided into 3 categories i.e., normal $(<110 \mathrm{mg} / \mathrm{dl})$, borderline $(110-129 \mathrm{mg} / \mathrm{dl})$, and high $(\geq 130 \mathrm{mg} / \mathrm{dl})$. HDL cholesterol was considered a risk factor if the level was $<35 \mathrm{mg} / \mathrm{dl}$. Normal triglyceride was $<200 \mathrm{mg} /$ dl. ${ }^{22}$ Hyperlipidemia was defined as $\geq 1$ of the lipid profile values above normal. ${ }^{23}$ Obesity was defined as BMI (body mass index) i.e., body weight (in $\mathrm{kg}$ ) divided by squared body height (in $\mathrm{cm}$ ), above the 95 $5^{\text {th }}$ percentile of CDC BMI 2000 curve. $^{24,25}$ For those aged above 20 year-old the BMI cutoff point was $>27 \mathrm{~kg} / \mathrm{m}^{2,26}$. Blood pressure was taken three times. Hypertension was defined as systolic or diastolic values above the $95^{\text {th }}$ percentile for age and sex according to Task Force on Blood Pressure Control in Children. ${ }^{27}$ For those aged above 18 year-old hypertension was established if the blood pressure was $\geq 140 / 90$ mmHg. ${ }^{28,29}$ Active smoker was defined if a subject had been smoking at least 100 cigarettes and still smokes until now. ${ }^{30,31}$ Passive smoker was defined if the subject was a non-smoker and was exposed to cigarette's smoke from a smoker for ${ }^{3} 1$ hour/ week during the last one year. ${ }^{32}$ The exposure included the side stream and the mainstream smoke. Side stream smoke was the smoke from the burning end of the cigarette between two puffs and the smoke that diffused through the cigarette paper. Mainstream

Table 1. Demographic characteristics of the SUBJECTS ( $N=63$ ) AND THE PARENTS $(\mathrm{N}=34)$

\begin{tabular}{lll}
\hline Variable & N & Percent \\
\hline Sex & & \\
$\quad$ Male & 34 & 54 \\
$\quad$ Female & 29 & 46 \\
Age (years) & & \\
$12-18$ & 37 & 59 \\
$19-25$ & 26 & 41 \\
& & \\
Premature CHD patients & & \\
$\quad$ Father & & \\
$\quad$ Mother & 295 & \\
Age of premature CHD & & \\
patients & & \\
$\quad \leq 45$ & 4 & \\
$\quad 46-50$ & 13 & \\
$51-55$ & 13 & \\
$\quad>55$ & 4 & \\
Age of $1^{\text {st }}$ attack & & \\
$\quad \leq 40$ & 4 & \\
$41-45$ & 8 & \\
$46-50$ & 17 & \\
$51-55$ & 5 & \\
\hline
\end{tabular}


Table 2. Distribution of Risk factors in the subjects

\begin{tabular}{|c|c|c|}
\hline CHD risk factors & $\mathbf{N}$ & Percent \\
\hline \multicolumn{3}{|l|}{ Smoking } \\
\hline Active smoker & 13 & 21 \\
\hline Passive smoker & 26 & 41 \\
\hline Non smoker & 24 & 38 \\
\hline \multicolumn{3}{|l|}{ Physical activity } \\
\hline Irregular & 46 & 73 \\
\hline Regular & 17 & 27 \\
\hline \multicolumn{3}{|l|}{ Body mass index } \\
\hline Non obese & 5 & 89 \\
\hline Obese & 67 & 11 \\
\hline \multicolumn{3}{|l|}{ Blood pressure } \\
\hline Hypertension & 6 & 9 \\
\hline Not hypertension & 57 & 91 \\
\hline \multicolumn{3}{|l|}{ Total cholesterol (mg/dl) } \\
\hline$<170$ & 40 & 63 \\
\hline $170-199$ & 13 & 21 \\
\hline$\geq 200$ & 10 & 16 \\
\hline \multicolumn{3}{|l|}{ LDL cholesterol (mg/dl) } \\
\hline$<110$ & 44 & 70 \\
\hline $110-129$ & 9 & 14 \\
\hline$\geq 130$ & 10 & 16 \\
\hline \multicolumn{3}{|l|}{ HDL cholesterol (mg/dl) } \\
\hline$<35$ & 3 & 5 \\
\hline$\geq 35$ & 60 & 95 \\
\hline \multicolumn{3}{|l|}{ Triglyceride (mg/dl) } \\
\hline$<200$ & 58 & 92 \\
\hline$\geq 200$ & 5 & 8 \\
\hline \multicolumn{3}{|l|}{ Hyperlipidemia } \\
\hline Yes & 25 & 40 \\
\hline No & 38 & 60 \\
\hline
\end{tabular}

smoke was the smoke that was inhaled into the smoker's lungs which was then exhaled. ${ }^{31,33,34}$ Regular activity was defined if a subject did aerobic exercise, such as jogging, walking, swimming, volley ball, basket ball, 3 to 5 times a week for 20 - 60 minutes each time. ${ }^{35}$

All data were recorded in a particular form. Descriptive data are presented in text, tables and graph- ics. Data were statistically calculated using SPSS version 10.0.

\section{Results}

We reviewed 63 children from 34 premature CHD patients who agreed to join the study. The characteristics of study subjects and premature CHD patients are seen in Table 1 .

This table shows that there were more boys than girls ( $54 \%$ vs. $46 \%)$. Children aged $12-18$ year-old were more frequent (59\%) than those aged 19-25 year-old (41\%). Premature CHD occurred most often in male (29 out of 34 ) and at the age group of 4650 and $51-55$, the median age was 50.6 year-old. The first attack of myocardial infarctions occurred mostly at the age of $46-50$.

Table 2 shows that most subjects were passive smokers and the minority were active smokers. Most did not do any regular exercise. Body mass index examination showed that most subjects were non obese. Most of the subjects had normal blood pressure, normal total cholesterol level, normal LDL, and normal HDL cholesterol level. Triglyceride level was normal in most of the subjects. Hyperlipidemia was seen in $40 \%$ of the subjects. Figure 1 shows that most of the subjects had 3 risk factors.

Figure 2 shows that the most frequent risk factors found in patients with premature CHD were irregular exercise, hypertension, obesity, smoking, hyperlipidemia, diabetes mellitus, and family history of CHD, consecutively.

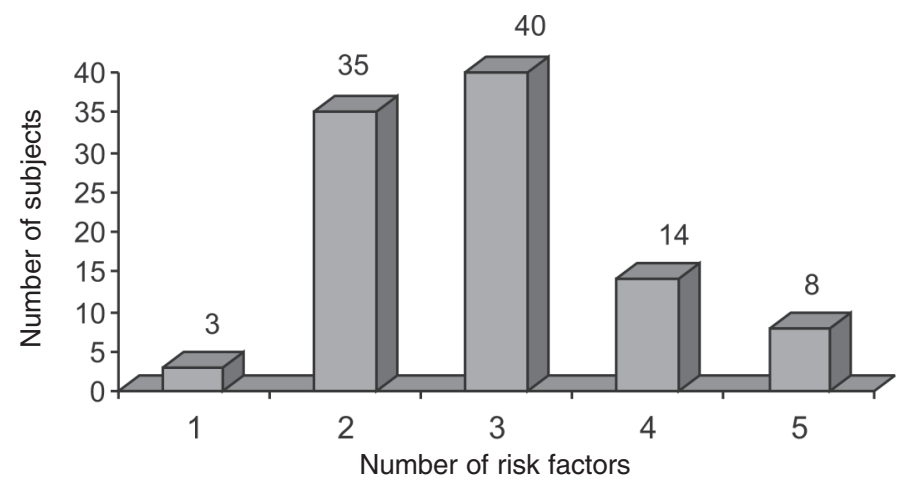

Figure 1. Number of risk factors of CHD in children 


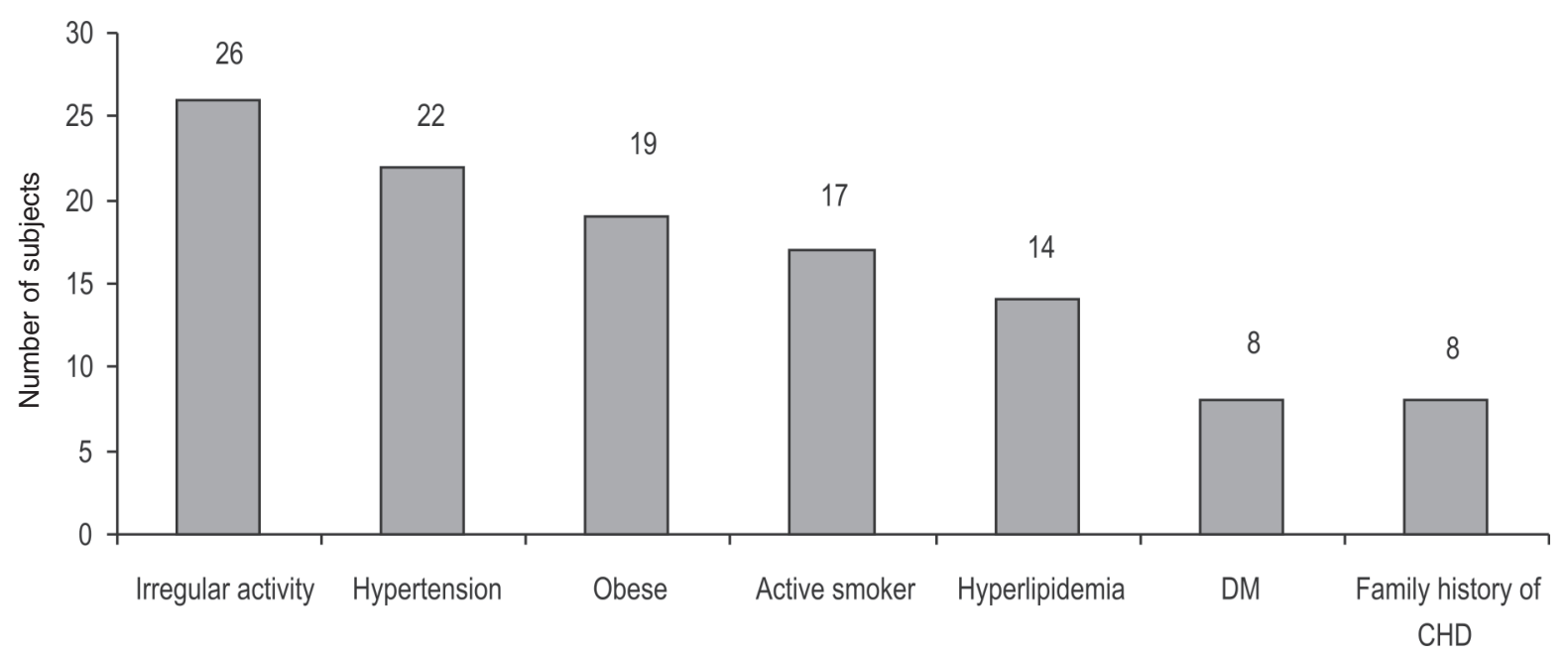

Figure 2. Distribution of risk factors in premature CHD patients $(n=34)$

\section{Discussion}

The frequency of passive smokers in this study was (41\%) twice than active smokers (21\%), while the rest of the subjects was non-smoker (38\%). National household survey (SKRT) 1995 showed the prevalence of male and female smokers older than 10 year-old was $45 \%$ and $1.5 \%$, respectively. A survey by Lembaga Menanggulangi Masalah Merokok (LM3) performed at a public high school (SMU 8 Jakarta) found that the prevalence of smoker was only $7.4 \%{ }^{36}$ Howard et al. found that in adults the prevalence of active smokers, passive smokers and non-smokers were $27 \%, 26 \%$ and, $14 \%$, respectively. ${ }^{32}$ These figures are different from our study because of the differences in age group (where subjects in Howard's study aged 45 - 65 year-old) and operational definition used. The high prevalence of passive smokers in our study needs a great concern because the literatures said that being passive smokers could fasten atherosclerosis process and increase the risk of CHD. ${ }^{37}$

Only $27 \%$ of subjects in this study had routine physical activity, $73 \%$ of subjects did not do it routinely. This result is almost the same with the study by Djer on elementary school children with obesity where he found $76.1 \%$ of subjects did low level physical activity while $23.9 \%$ did moderate-hard physical activity. ${ }^{38}$ In contrary, Bistritzer found that $85.1 \%$ was still active and $14.9 \%$ was not active. ${ }^{23}$ These differ- ences were due to age factor as Bistritzer evaluated subjects aged 2-20 years, or maybe because of the unawareness of subjects in our study about the importance of activity.

Based on BMI, we found that $11 \%$ of subjects were obese while Bistritzer found only $0.9 \% .{ }^{23}$ This difference was caused by different age groups, where Bistritzer subjects aged 2-20 years while in this study the subjects were $12-25$ year-old. This result supports the evidence that BMI will increase as subjects get older. ${ }^{39}$ Of elementary school children from middlelower socio-economical status, Djer found that the prevalence of obesity was $9.6 \%,{ }^{38}$ whereas Meilany found the prevalence of obesity in elementary school children from middle-high socio-economic status was $27.5 \% .{ }^{40}$ Both studies did not assess the influence of socio-economical status on the prevalence of obesity.

Nine percent of subjects in our study had hypertension. This result is higher compared to a study by Djer which found hypertension of $2.8 \% .{ }^{38}$ Ariani et al. found the prevalence of hypertension in elementary school children live in the hill area $(10.2 \%)$ was not significantly different compared to those who live in seashore (11.8\%). ${ }^{41}$ Norwood found out that the prevalence of hypertension in children is $1-3 \%$ and in adult it increased up to 20\%.42 Besides subjects' age, the difference was also because the subjects of this research were the offspring of parents which $65 \%$ of them suffered from hypertension. ${ }^{42}$ 
We found $63 \%$ of the subjects had normal total cholesterol level, $21 \%$ had borderline and $16 \%$ had high cholesterol level. Bistritzer found slightly different result i.e., $42.9 \%$ of subjects had normal cholesterol level, 32.8\% had borderline and 24.3\% had high level of total cholesterol. ${ }^{23}$ Munir found that $31 \%$ of middle to upper social economic elementary school children had hypercholesterolemia and 28\% had borderline level. ${ }^{43}$ Our study also found a significant difference of cholesterol level between obese and non obese patients. Meilany found a similar result, i.e $33.1 \%$ of elementary school children had cholesterol level $>200 \mathrm{mg} / \mathrm{dl} .{ }^{40}$ Djer in his study on obese children from middle to lower social economic group found a slightly lower prevalence of hypercholesterolemia i.e., 25\%. ${ }^{38}$ The difference between these results might be due to social economic difference which is a risk factor of obesity, whereas obesity is also a risk factor of hypercholesterolemia. The subjects of our study consisted of obese and non-obese patients. Djer found that the mean cholesterol level among obese children were $180.3 \mathrm{mg} / \mathrm{dl},{ }^{38}$ while Meilany found of $226.6 \mathrm{mg} / \mathrm{dl},{ }^{40}$ and Munir, 195.7 $\mathrm{mg} / \mathrm{dl},{ }^{43}$ whereas in our study we found $166.7 \mathrm{mg} / \mathrm{dl}$. Our results were similar with the result of Gerung's study i.e., $166.2 \mathrm{mg} / \mathrm{dl} .{ }^{44}$

Our study found $70 \%$ of the subjects had normal LDL cholesterol level, 14\% had borderline, and $16 \%$ had high level, whereas Bistritzer found 34.5\% subjects had normal level of LDL cholesterol, $40.2 \%$ had borderline, and $25.3 \%$ had high level. ${ }^{23}$ Rifai found $26 \%$ children with parental history of premature CHD or hypercholesterolemia had LDL cholesterol level $>110 \mathrm{mg} / \mathrm{dl}, 7 \%$ of which had level $>130 \mathrm{mg} / \mathrm{dl} .{ }^{45}$ Munir found 39\% of his obese subjects had normal level, $36 \%$ had borderline, and 24\% had high level of LDL cholesterol. ${ }^{43}$ The difference in age group and obesity status might cause the difference between the result of our study and other studies. The mean value of LDL cholesterol level from our study was $97.7 \%$. Djer found a higher value among obese children (113.3 $\mathrm{mg} / \mathrm{dl}$ ), whereas among the non-obese children it was $102.4 \mathrm{mg} / \mathrm{dl} .^{38}$ The Munster Heart Study found that among normal population aged $16-25$ year-old, the mean of LDL cholesterol level were $98 \mathrm{mg} / \mathrm{dl}$ (in male) and $105 \mathrm{mg} / \mathrm{dl}$ (in female). ${ }^{46}$ Gerung found a lower value among children aged $5-15$ year-old $(74.9 \mathrm{mg} /$ dl). ${ }^{44} \mathrm{LDL}$ cholesterol level is also determined by age and BMI. The older the age and the higher the BMI, the higher LDL cholesterol level. ${ }^{46}$

Our study found that $5 \%$ of the subjects had low HDL cholesterol level and 95\% were normal. Bisritzer found $16.8 \%$ of his subjects had low level and $83.2 \%$ had normal level of HDL cholesterol. He also found that low HDL cholesterol level was closely related with irregular exercise. ${ }^{23}$ The mean HDL cholesterol level of our study $(48.2 \mathrm{mg} / \mathrm{dl})$ was similar to the result from Djer's study $\left(48.6 \mathrm{mg} / \mathrm{dl}\right.$ ) among normal population, ${ }^{38}$ whereas Gerung found a lower value $(46.8 \mathrm{mg} / \mathrm{dl}){ }^{44}$ Munir found that the mean value of HDL cholesterol in normal population $(56.2 \mathrm{mg} / \mathrm{dl})$ was not so different from that of the obese group $(55.8 \mathrm{mg} / \mathrm{dl}) .{ }^{43}$

Most of our subjects (92\%) had normal triglyceride level. This result was better compared to Bisritzer's study that found $65.4 \%$ of subjects had normal and 34.6\% had high level of triglyceride level. As with HDL cholesterol, triglyceride level is also affected by physical activity. ${ }^{23}$ Djer found the mean triglyceride level among obese children was $120.7 \mathrm{mg} / \mathrm{dl}$ and among the normal population was $91.8 \mathrm{mg} / \mathrm{dL} .{ }^{38}$ Munir found that the mean triglyceride level among the obese children was $114.4 \mathrm{mg} / \mathrm{dl}$ and among the normal population was $81.2 \mathrm{mg} / \mathrm{dl} .{ }^{43}$ Our study found it was $93.1 \mathrm{mg} / \mathrm{dl}$, similar to the result from normal population in the Djer's study.

Our study found that the prevalence of hyperlipidemia in children and young adults with family history of premature $\mathrm{CHD}$ was $40 \%$, almost similar to the result from Bisritzer's study (42\%). ${ }^{23}$ This result was twice higher than the prevalence of hyperlipidemia in normal population $(10-12 \%) .{ }^{47}$ It is obvious that parental history of premature CHD is a risk factor for hyperlipidemia in children and might be asymptomatic.

Only 3\% of the subjects had one risk factor for CHD i.e., parental history of premature CHD. Most (40\%) had 3 risk factors, $35 \%$ had 2 risk factors, $14 \%$ had 4 risk factors, and $58 \%$ had 5 risk factors. Risk factors of CHD in our study were parental history of premature $\mathrm{CHD}$, hyperlipidemia, hypertension, obesity, active or passive smoker, and irregular activity. Many studies found that the more risk factors one had, the higher the incidence of CHD. ${ }^{16-18,48}$ Parental history of premature CHD facilitated the other risk factors such as hyperlipidemia, hypertension, diabetes and obesity. ${ }^{21}$ In this study, we identified that 
premature $\mathrm{CHD}$ occurred in male more often than in women. It is in accordance with studies in the literature that one of the risk factor of CHD was male gender. ${ }^{19}$

The age group of $\mathrm{CHD}$ patients in this research is divided into 4 groups with the median of 50.6 year old. This was different from Bistritzer's research that found the mean of the subjects' age was about 30 years old (31-41 years old). This different is caused by the using of age criteria, where Bistritzer studied on subjects $<40$ year old. ${ }^{23}$ The first acute myocardial infarct attack have a high incidence at the age group of 45-60 year old $(40 \%)$ with the mean of 45.9 year old.

Figure 2 shows that the most common risk factor of CHD in premature CHD patients was irregularly activity (26 out of 34). Kusmana has identified subjects that had never done sport activity was $50.9 \%$, and they who was doing sport rarely was $28.8 \% .{ }^{49}$ The common reasons for not doing sport were busy and had no power to do even for mild sport. This habit was still continuing even though they knew that regular sport was very important to maintain their health.

Twenty two out of 34 premature CHD patients had hypertension. Schacinger et al. found that subjects with family history of CHD had higher frequency of hypertension compared to them without such history. ${ }^{20}$ Bistritzer found $20.6 \%$ of his subjects had hypertension, ${ }^{23}$ while Nora found hypertension in $21 \% .{ }^{16}$ These results were not quite different with Hopskin's research in the population with familial hypercholesterolemia and with premature CHD which found $19.1 \%$ patients had hypertension. ${ }^{50}$ For comparison, a study found only $14 \%$ in normal population that had hypertension. ${ }^{49}$

Active smoker as one of the risk factor of CHD were found in 17 out of 34 premature CHD patients. Bistritzer also identified $79 \%$ of premature CHD patients were active smokers. ${ }^{23}$ In population of premature CHD patient with hypercholesterolemia 26.5\% are active smoker, two times higher than those without premature CHD (12.8\%). ${ }^{50}$ In normal population, National household survey (SKRT) 1986 showed that male smokers was about $52.9 \%$ and female smokers was about $3.6 \% .{ }^{34}$ Kusmana found $33.6 \%$ of his research subjects were active smokers, ${ }^{49}$ while Howard found only $27 \% .^{32}$ The tendency of active smokers in developed countries seems lower to the awareness of the danger of smoking increased.
Hyperlipidemia occurred in 14 out of 34 premature CHD patients. Bistritzer found $77 \%$ parents of premature CHD patients had abnormal lipid profile. ${ }^{23}$ In this research, we took the data of hyperlipidemia from medical records and not all of premature CHD patients had this data. This was one of the weaknesses of this research.

The history of CHD in family was found in 8 of 34 premature CHD patients. Bistritzer found 64.7\% in his subjects, ${ }^{23}$ while Nora found $61 \% .{ }^{16}$ This difference comes out because the subjects might not exactly know the ill history in their family.

Diabetes Mellitus (DM) as a risk factor was only found in 8 subjects. Nora found only in 6\%, though it was three times compared to control (2\%). ${ }^{16}$ Schachinger also found that DM was frequent in population with CHD. It was not quite different with Hopskin's study. A study showed that only 5.9\% of subjects with premature CHD came from family with hypercholesterolemia have $\mathrm{DM} .{ }^{50}$ The higher prevalence of DM in our study was due to the data taken from medical record at that time of CHD attack and no examination of blood glucose level during this research.

In conclusion the prevalence of passive smokers, irregular activity, obese, hypertension and hiperlipidemia in this research were higher than normal population and $97 \%$ of subjects had more than one risk factors of CHD. It is important to do a screening to know the risk factors of CHD (hypertension, hyperlipidemia, obesity, and physical activity) in children with history of premature CHD in their parents, so we can prevent CHD.

\section{References}

1. Celemajer DS, Sorensen KE, Deanfild JE. Atherosclerosis: a disease that begins in childhood. Cardiol Young 1994:224-6.

2. Cotran RS, Kumar V, Robbins SL, Schoen FJ. Pathologic basis of disease. $5^{\text {th }}$ ed. Philadelphia: Saunders, 1994. p. 473-84.

3. Mortality patterns - United States 1997. JAMA 1999; 282:1512-3.

4. Chu NF, Rimm EB, Wang DJ, Liou HS, Shieh SM. Clustering of cardiovascular disease risk factors among obese school children: The Taipei Children Heart Study. Am J Clin Nutr 1998; 67:1141-6. 
5. Ranuh IGN. Indonesian health profile. Unpublished data.

6. Pelupessy JM. Penyakit jantung koroner. In: Sastroasmoro S, Madiyono B, editors. Buku ajar kardiologi anak. $1^{\text {th }}$ ed. Jakarta: Bina Rupa Aksara; 1994. p. 404-15.

7. Davies MJ, Woolf N. Atherosclerosis: what is it and why does it occur? Br Heart J 1993; 69 (suppl): S3S11.

8. Krovetz LJ, Gessner IH, Schielberg GL. Handbook of pediatric cardiology. $2^{\text {nd }}$ ed. Baltimore: University Park Press; 1979. p. 417-23.

9. PDAY Research Group. Relationship of atherosclerosis in young men to serum lipoprotein cholesterol concentration and smoking. JAMA 1990:30;18-24.

10. Newburger JW. Dyslipidemia in childhood and adolescence. In: Fyler DC, editor. Nadas Pediatric Cardiology. Singapore: Hanley \& Belfus; 1992. p. 285-93.

11. Snetselaar L, Lauer RM. Childhood. Diet and the atherosclerosis process. Nutr Today 1992:22-7.

12. Mc Gill HC, Mc Mahan CA, Zieske AW, Tracy RE, Malcom GT, Herderick EE, et al. Association of coronary heart disease risk factors with microscope qualities of coronary atherosclerosis in youth. Circulation 2000;102:374-9.

13. Strong JP, Oalman MC, Malcolm GT. Atherosclerosis in youth: relationship of risk factors to arterial lesions. In: Filer LJ, Lauer RM, Luepker RV, editors. Prevention of atherosclerotic and hypertension begining in youth. Philadelphia: Lea \& Febiger; 1994. p. 13-8.

14. Enos WF, Holmes RH, Bayer J. Coronary disease among United States soldiers killed in action in Korea: preeliminary report. J Am Med Assoc 1953;152:1090-3.

15. Klag MJ, Ford DE, Mead LA, He J. Serum cholesterol in young men and subsequent cardiovascular disease. N Engl J Med 1993;328:313-8.

16. Nora JJ, Lortscher RH, Spangler RD, Nora AH, Kimberling WJ. Genetic- epidemiologic study of earlyonset ischemic heart disease. Circulation 1980;61:503-8.

17. Davis J. Family history of heart disease: a definition who should worry? WebMD Corporation 2001.

18. Williams RR, Hopkins PN, Wu LL, Schumacher C, Hunt SC. In: Pearson TA, Crigui MH, Luepker RV, editors. Primer in preventive cardiology. American Heart Association. Texas: Boehringer Ingelheim Pharmaceuticals Inc; 1994. p. 93-106.
19. Libby P. Atherosclerosis. In: Fauci AS, Braunwald E, Isselbacher KJ, Wilson JD, Martin JB. editors. Harrison's principles of internal medicine. $14^{\text {th }}$ ed.USA: Mc Graw Hill; 1998. p. 1345-52.

20. Schachinger V, Britten MB, Elsner M, Walter DH, Scharer I, Zeiher AM. A positive history of premature coronary artery disease is associated with impaired endothelium dependent coronary blood flow regulation. Circulation 1999;100:1502-8.

21. Family factor predicts heart disease risk. Medical Tribune. Maret 2001.

22. American Academy of Pediatrics. Cholesterol in childhood. Pediatrics 1998;101:141-7.

23. Bistritzer T, Rosenzweig L, Barr J, Mayer S, Lahat E, Faibel $\mathrm{H}$, et al. Lipid profile with paternal history of coronary heart disease before age 40. Arch Dis Child 1995; 73:62-5.

24. Hammer LD, Kraemer HC, Wilson DM, Ritter PL, Dornbusch SM. Standardized percentile curves of bodymass index for children and adolescents. AJDC 1991; 145:259-63.

25. Dietz WH, Bellitzi MC. Introduction: the use of body mass index to assess obesity in children. AM J Clin Nutr 1999; 70 (suppl):123S-5S.

26. Suyono S. In: Alwi I, Setiati S, Sudoyo AW, Bawazier LA, Kasjmir YI, et al, editors. Pertemuan ilmiah tahunan ilmu penyakit dalam. Penatalaksanaan obesitas secara rasional: farmakologis dan non farmakologis. Jakarta: Pusat Informasi dan Penerbitan Bagian Ilmu Penyakit Dalam FKUI; 2001.

27. Daniels SR. Hypertension: diagnosis and treatment in childhood and adolescence. In: Filler LJ, Lauer RM, Luepker RV, editors. Prevention of atherosclerosis and hypertension begining in youth. Philadelphia: Lea \& Febiger; 1994. p. 234-42.

28. Susalit E. In: Alwi I, Bawazier LA, Kolopaking MS, Syam AF, Gustaviani R, editors. Simposium penatalaksanaan kedaruratan di bidang ilmu penyakit dalam II. Penatalaksanaan krisis hipertensi. Jakarta: Pusat Informasi dan Penerbitan Bagian Ilmu Penyakit Dalam FKUI; 2002.

29. Stevens LM,Lynm C,Glass R. Hypertension.JAMA 2002;287:1070.

30. Cigarette smoking among adults. Available from: URL:http://www upenn.edu.

31. Slama K. In: International union against tuberculosis and lung disease. Tobacco control and prevention. A guide for low- income countries. USA; 1998. 
32. Howard G, Burke GL, Szklo M, Tell GS, Eckfeldt J, Evans $\mathrm{G}$, et al. Active and passive smoking are associated with increased carotid wall thickness. The atherosclerosis risk in communities (ARIC) study. Arch Intern Med 1994;154:1277-82.

33. Passive smoking against health. What is passive smoking? <index htm>ã copyright.

34. Aditama TY. In: Patarai AAP, editor. Masalah merokok dan penanggulangannya. Jakarta: Ikatan Dokter Indonesia; 2001.

35. Heyward VH. In: Advanced fitness assesment exercise prescription. Designing cardiorespiratory exercise programs. $3^{\text {th }}$ ed.USA: Human Kinetics; 1998. p.83-104.

36. Aditama TY. In: Youth \& tobacco Indonesian experience. Indonesian smoking control foundation. Presented at:WHO SEARO workshop on "youth \& tobacco"; 1999 August 26-27; Mumbai, India.

37. Moskowitz WB, Schwartz PF, Schieken RM. Childhood passive smoking, race, and coronary artery disease risk. Arch Pediatr Adolesc Med 1999;153:446-453.

38. Djer MM. Prevalens obesitas pada anak usia sekolah dasar di SD Kenari 7 dan 8 Jakarta dan faktor-faktor yang mempengaruhi [thesis]. Jakarta: Bagian IKA FKUI 1998.

39. Maynard LM, Wisemandle W, Roche AF. Childhood body composition in relation to body mass index. Pediatrics 2001;107:344-50.

40. Meilany TA. Profil klinis laboratorium serta sikap dan perilaku murid sekolah dasar dengan obesitas [thesis]. Jakarta: Bagian IKA FKUI 2002.

41. Ariani A, Lisma E, Lubis IZ, Ramayati R, Rusdidjas. Blood pressure values of elementary school-age children at the highland and seashore areas. Paediatr Indones 2000;40:24-9.
42. Norwood VF. Hypertension. Pediatrics in review 2002;23:6.

43. Munir M, Darmoprawiro S. Blood lipid of preadolescent boys of well-to-do families. Paediatr Indones 2001;41:19-26.

44. Gerung JILL. Hubungan beberapa faktor risiko aterosklerosis dengan profil lipid pada anak dalam konteks kardiologi preventif [thesis]. Menado: Bagian IKA FK UNSRAT; 2000.

45. Rifai N, Neufeld E, Ahlstrom P, Rimm E, D’Angelo L, Hicks JM. Failure of current guidelines for cholesterol screening in urban african-american adolescents. Pediatrics 1996;98:383-8.

46. Dominiczak MH. Hyperlipidaemia and cardiovascular disease. Current opinion in lipiodology 2000;11:91-2.

47. Pitkanen OP, Nuutila P, Raitakari OT, Porkka K, Iida $\mathrm{H}$, Nuotio I, et al. Coronary flow reserve in young men with familial combined hyperlipidemia. Circulation 1999;99:1678-84.

48. Berenson GS, Srinivasan SR, Bao W, Newman WP, Tracy RE, Wattigney WA. Association between multiple cardiovascular risk factors and atherosclerosis in children and young adult. $\mathrm{N}$ Engl J Med 1998;338:1650-6.

49. Kusmana D. Pengaruh tidak/stop merokok disertai olahraga teratur, dan/atau pengaruh kerja fisik terhadap daya survival penduduk di Jakarta:penelitian kohort selama 13 tahun. Ringkasan disertasi. Jakarta: FKUI; 2002.

50. Hopkins PN, Stephenson S, Wu LL, Riley WA, Xin Y, Hunt SC. Evaluation of coronary risk factors in patients with heterozygous familial hypercholesterolemia. Am J Cardiol 2001;87:547-53. 